\title{
4차 산업혁명의 선도국 전략과 후발국 대응 방안
}

목차

I. 4차 산업혁명과 산업 패러다임의 변화

1. 4차 산업혁명이란?

2. 4차 산업혁명을 가속화하는 미래 트렌드

3. 산업 패러다임의 변화 방향

II. 선도국의 전략: 독일과 미국을 중심으로

1. 독일: 스마트팩토리 기반의 제조 서비스 모델

2. 미국: 스마트시티 기반의 플랫폼 서비스 모델

III. 후발국으로서 우리나라의 대응 전략

IV . 개발도상국과 협력 방향

참고 문헌 


\section{요 약}

4차 산업혁명의 대표적인 선도 국가는 독일과 미국이다. 독일은 스마트팩토리 중심의 제조 서비스 전략을 강조하고, 미국은 스마트시티 기반의 플랫폼 서비스 전략을 강조한다. 양국의 목표에는 자국의 제조 및 도시 경쟁력을 강화하겠다는 것 외에 관련된 하드웨어와 소프트웨어를 패키지로 수출하고, 다양한 파생 사업을 통한 수익 창출도 포함되어 있다.

우리나라는 제조 강국이지만, 4차 산업혁명과 관련해서는 후발국의 지위에 있다. 선도국과 대등한 위치에서 4차 산업혁명 시대에 주도권을 확보하기 위해서는 하드웨어가 아닌 데이터 소유권과 이에 기반을 둔 소프트웨어 경쟁력이 필요하다. 더불어 국가 간 협력이 아닌, 도시 간 협력을 강조한다면 선진국은 물론 개발도상국의 주요 도시와 다양한 협력 기회가 있을 수 있다.

주제어 : 4차 산업혁명, 독일, 미국, 스마트팩토리, 스마트시티 


\section{I . 4차 산업혁명과 산업 패러다임의 변화}

\section{4차 산업혁명이란?}

제조업은 역사적으로 총 3번의 산업혁명을 경험하였다.

1 차 산업혁명은 18 세기 후반 제임스 와트(James Watt)의 증기기관에서 시작되었다. 1784년에

최초의 기계식 방직기가 개발되면서 생산성이 획기적으로 향상된 것이다. 또한 2차 산업혁명은 20세기 초반 미국의 헨리포드(Henry Ford)가 신시네티 도축장의 컨베이어 벨트 시스템을 자동차 모델 $\mathrm{T}$ 생산에 적용하면서 시작되었다. 전기 에너지와 켄베이어 벨트, 분업 효과가 맞물리며 대량생산이 본격화되었다. 그리고 3차 산업혁명은 1970년대 PLC(Programmable Logic Controller)1)가 개발되면서 시작되었다. 전자와 기계 산업이 결합(메카트로닉스)되면서 자동화가 가속화된 것이다. 사람의 노동을 대체할 것이라는 우려도 있었지만, 생산성이 비약적으로 향상 되었음을 부인하지 못한다. 한편, 인간의 노동력을 복합적이고 전문적인 영역으로 이동시키는 계기가 되었다는 시각도 있다.

〈그림 1〉 산업혁명의 역사적 흐름

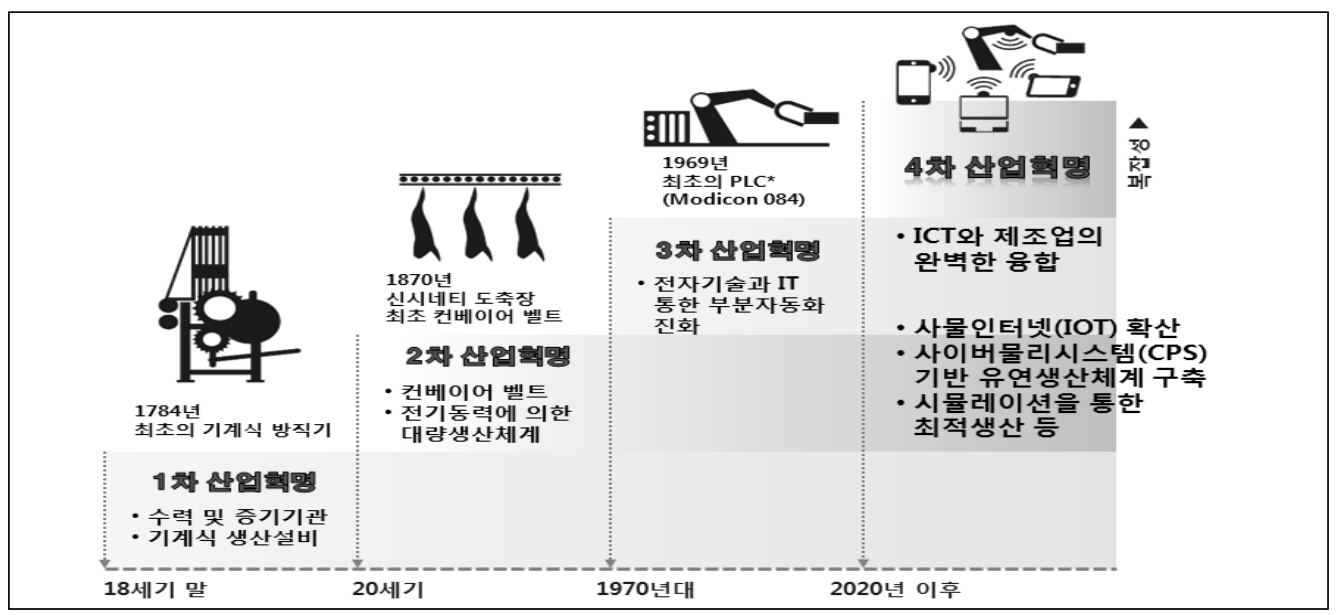

출처: 박형근 (2014)

1) 기존 생산 공정에서 사용하던 릴레이, 타이머, 카운터 등의 기능을 반도체 소자로 대체시킨 산업용 제어 컨트롤러다. 디지털 또는 아날로그 입-출력부를 매체로 하여 여러 가지 형태의 기계나 공정을 제어하기 위하여 논리, 연산, 계수, 순차 처리 등의 특별한 기능을 수행할 수 있는 명령어들을 내부에 저장할 수 있고, 제어 알고리듬(Algorithm)의 실행 명령을 프로그램화 할 수 있다(네이버 백과사전). 
4차 산업혁명은 자동화가 극대화(extreme automation)되고, 연결성도 극대화(extreme connectivity)되는 시대를 의미한다(윤유리, 2017). 사물인터넷(Internet of Things, 이하 $\mathrm{IoT}$ ) 기기가 폭발적으로 증가하고, 각 기기가 고유 IP(internet protocol) 주소를 할당받아 서로 소통을 하면서 산업 생산성은 언제나 극대화 상태가 유지된다. 새롭게 발명된 동력원은 없지만 기존의 동력원을 사람이 아닌 사물까지 활용하는 시대, IoT와 산업생태계가 완벽하게 융합되는 것이 4차 산업혁명의 핵심이다. 전문가들은 이러한 시대가 약 2025년부터 가속화될 것으로 보고 있다(김영훈, 2015).

\section{4차 산업혁명을 가속화하는 미래 트렌드}

첫째, 소비의 개인화(Personalization) 성향이 강해지고 있다. Ford에 의해 촉발된 대량생산 시대는 제품별 생산원가를 낮춰 많은 사람이 자동차라는 고가품을 구매할 수 있게 해 주었다. 하지만 1960년대부터 남들과 차별적인 제품을 선호하는 소비자들이 증가하기 시작했다. 맞춤 제품에 대해 15 20\%의 가격 프리미엄을 지불하려는 소비자와 맞춤 생산(Customization)을 통해 이 시장을 선점하려는 공급자가 만나면서 시장이 형성되고 있다. 자동차, 항공기, 특수기계, 전자산업을 중심으로 확산되기 시작한 맞춤 생산 체계는 대량생산에 적합하다고 알려져 있는 화학, 금속 산업에까지 확대되고 있는 추세다.

미래에는 맞춤 생산 추세가 극단화되면서 개인화 생산 시대가 도래할 것이다. 산업의 모든 밸류체인(value chain)이 IoT로 연결되면서 고객 주문별로 생산라인이 가변화되는 극단적인 유연생산 체계가 가능해진다. 소비자가 지불하는 프리미엄 가격이 생산자의 다품종 소량 생산의 비용 부담을 상쇄하면서 맞춤 생산이 시장을 주도하는 등 산업생태계의 구조가 근본적으로 변할 것이라고 보고 있다. 4 차 산업혁명이란 이러한 변화가 일상화된 시대다. 
〈그림 2〉 4차 산업혁명과 개인 맞춤 생산시대의 도래

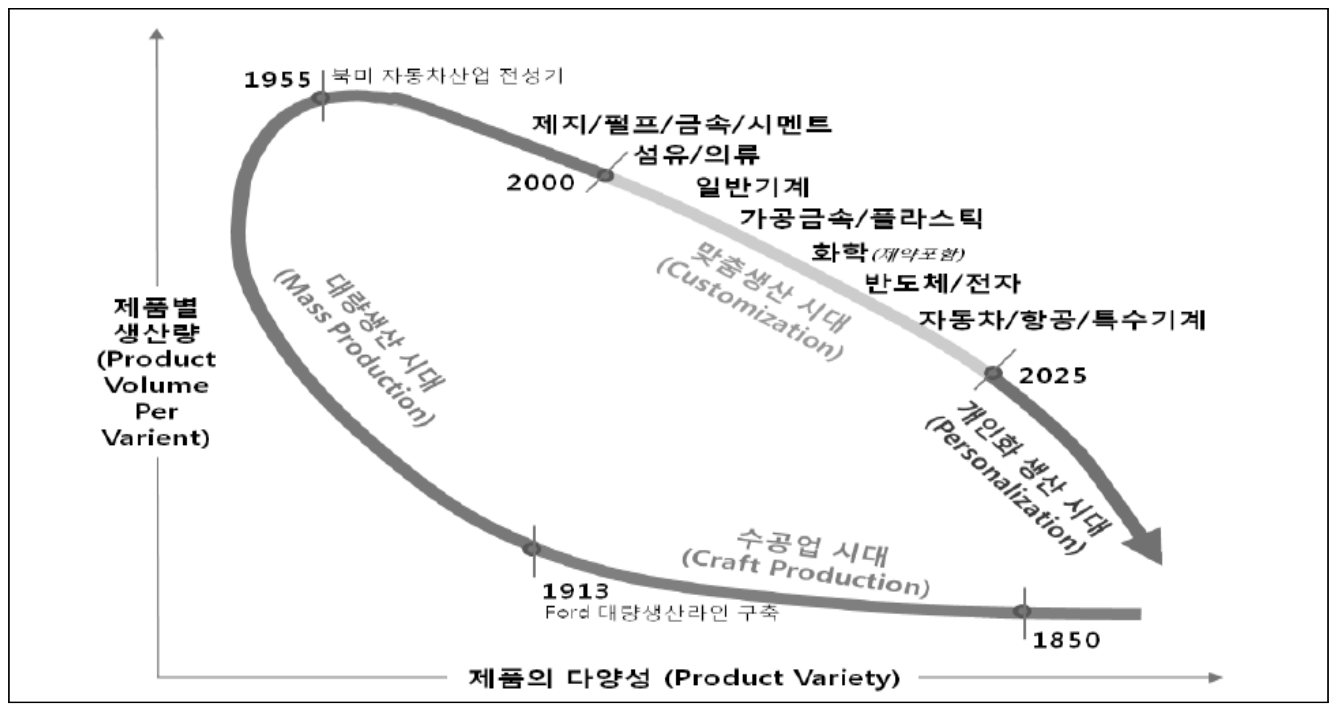

출처: Yoram Koren (2010), Florian Guldner (2015)

둘째, 도시화(Urbanization)의 진전으로 개인화 시대가 가속화되고 있다. 도시는 다양성을 특징으로 한다. 도시에 거주하는 $20 \%$ 의 개성 넘치는 소비자들이 남들과 차별적인 제품을 요구 하며 맞춤 시장을 성장시킨다. 도시화는 개인화 제품 생산으로 대표되는 4차 산업혁명을 가속화 시키는 중요 동인이다.

4차 산업혁명이 선진국에서 가속화될 수 있는 것도 도시화와 밀접한 관련이 있다. 북미와 유럽 등 선진국에서는 인구의 $80 \%$ 가 도시에 살고 있는데, 맞춤 제품을 선호하는 $20 \%$ 의 소비자를 만족시킬 수 있는 제품은 개발도상국의 공장에서는 생산되기 어렵다. 도시화는 개발도상국에서도 빠르게 확산되고 있다. 개발도상국 경제는 제조업이 미처 경쟁력을 확보하기 전에 서비스업으로 전환되는 조기탈산업화(Premature Deindustrialization) 현상을 겪고 있다. 공동화가 가속화 되는 농업 및 공업 부문은 4차 산업혁명의 자동화 및 지능화 기술을 요구하게 될 것이며, 도시화가 가속화되면서 선진국을 중심으로 발생될 것이라고 생각했던 맞춤 제품에 대한 니즈(needs)가 개발도상국에서도 빠르게 확대될 것이다.

셋째, 주요 국가의 생산가능인구가 감소하고 있고, 생산성을 근본적으로 향상시키기 위한 대비책이 요구되고 있다. 25세에서 49세까지를 생산성이 가장 높은 핵심 생산가능인구라고 정의한다. 독일, 일본, 미국, 한국 등 선진국에서 핵심생산인구 비중은 이미 하락 추세로 접어들었다. 이러한 인구 구조학적인 문제로 선진국의 많은 공장이 해외로 이전했지만, 문제는 개발도상국들의 핵심 생산인구 감소 속도가 생각보다 빠르다는 것이다. 중국은 이미 2015년부터 감소세가 시작 
되었고, 인도는 저렴한 노동력을 구할 수 있는 곳이지만 2030년까지다. 결국 많은 국가와 기업은 원가절감을 위해 생산기지를 계속 해외로 이전하는 것보다 자국에 유지시키되 자본생산성을 증가시키는 것이 근본적인 해결책이 될 수 있음에 공감하고 있다. 4차 산업혁명은 신기술 자본 투자, 새로운 관리 인력 육성을 통해 산업생산성을 최대화할 수 있기 때문에 많은 국가가 직면한 인구구조학적인 문제를 해결할 수 있는 근본적인 해결책이 될 수 있다.

\section{〈그림 3〉 주요국 핵심 생산가능인구 비중 추이 및 전망}

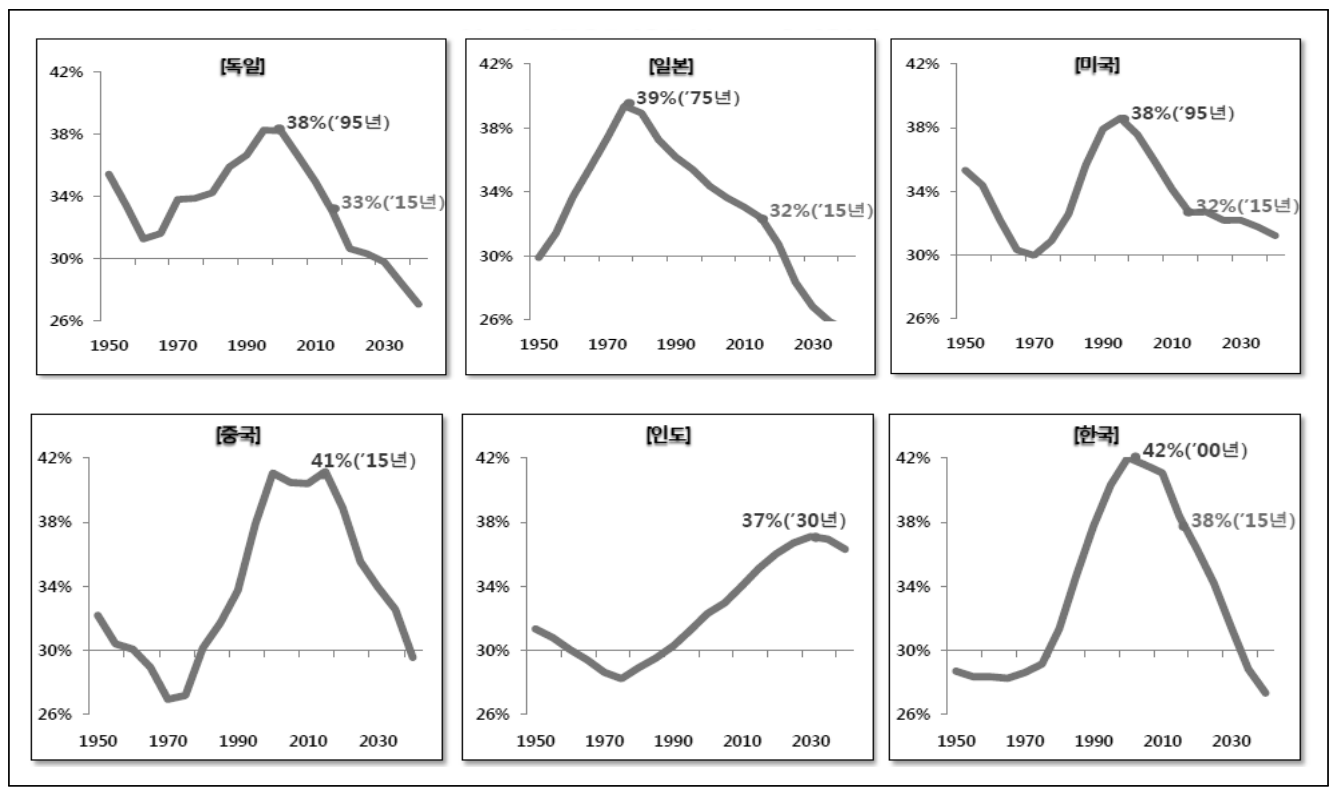

출처: UN 경제사회국(http://esa.un.org) (접속일:2018.05.27.)

넷째, 4차 산업혁명 기술이 동시다발적으로 발전하고 있다.

4차 산업혁명과 관련된 기술은 매우 다양하다. 하지만 대표 기술들이 동시다발적으로 발전하면서 가격이 하락하고 대중화되고 있다. 인공지능은 이미 의료-자동차 등 다양한 분야에서 활용되고 있고, $3 \mathrm{D}$ 프린팅은 시작품 제작 시장에서는 널리 활용되고 있으며, 최종 제품 시장에도 빠르게 침투하고 있다. 산업용 로봇은 일부 대기업의 대형 공장에서만 사용되었지만, 최근에는 3천만 원대의 범용 로봇이 등장하고 있으며 또 이와 함께 중소 제조업체들의 도입이 증가하고 있다. 4 차 산업혁명의 대표 제품인 센서 시장도 마찬가지다. 고가 제품으로 분류되었던 MEMS (Micro Electro Mechanical System) 센서는 2012년 이후 평균 판매 가격이 1달러 밑으로 하락하고 범용화가 가속화되고 있다. IoT, 로봇, 인공지능 등 핵심 기술과 이를 활용한 제품의 가격이 동시에 하락하면서 4차 산업혁명 시대가 이미 목전에 있다는 전망이 우세해지고 있다. 


\section{3. 산업 패러다임의 변화 방향}

\section{1) 부분 최적화에서 전체 최적화로 이동}

이제까지 산업의 밸류체인(value chain)은 완벽하게 통합되지 않았고 고객 주문, 생산 및 가공,

물류 및 유통, 애프터서비스(after service)가 별개로 움직였다. 생산 공장 내에서도 전공정(upstream)을 책임지는 부서와 후공정(downstream)의 부서는 소통하기 어려웠기 때문에 공장의 효율성은 최적화 상태에 있는 것은 아니었다. 물류와 유통, 애프터서비스는 외주사에 의존했기 때문에 전사 최적화를 달성하는 것은 매우 어려운 작업이었다. 고객들은 제품을 주문했을 때 어떤 생산 단계에 있는지, 생산자는 판매 이후 고객이 얼마나 만족하고 있는지 실시간으로 파악하지 못했다.

하지만 4차 산업혁명 시대에 산업 밸류체인은 IoT 하나로 연결된다. 이로 인해 고객 주문부터 애프터서비스까지 통합되는 앤드투엔드 엔지니어링(end to end engineering)이 가능해진다. 전사 최적화 관점에서 제조 생태계가 가동될 수 있는 것이다. 고객의 주문은 센서 칩에 저장되고, 센서가 부착된 반제품은 생산라인을 변화시키고 맞춤형 가공 프로그램을 지시한다. 설비들은 서로 소통하면서 최대 생산성이 가능한 가공방정식을 도출하고 제품이 완성되기 전에 출고, 판매, 유통시장에 관련 정보를 전송한다. 판매 이후에도 생산자는 제품의 상태를 실시간으로 모니터링 할 수 있다. 제품과 설비가 IoT로 서로 연결되어 있기 때문이다. 단지 모니터링 및 유지 보수 서비스 외에 IoT로 인해 생산자는 고객의 성향에 따른 다양한 서비스를 제공할 수 있다.

\section{〈그림 4〉4차 산업혁명과 산업 밸류체인 최적화}

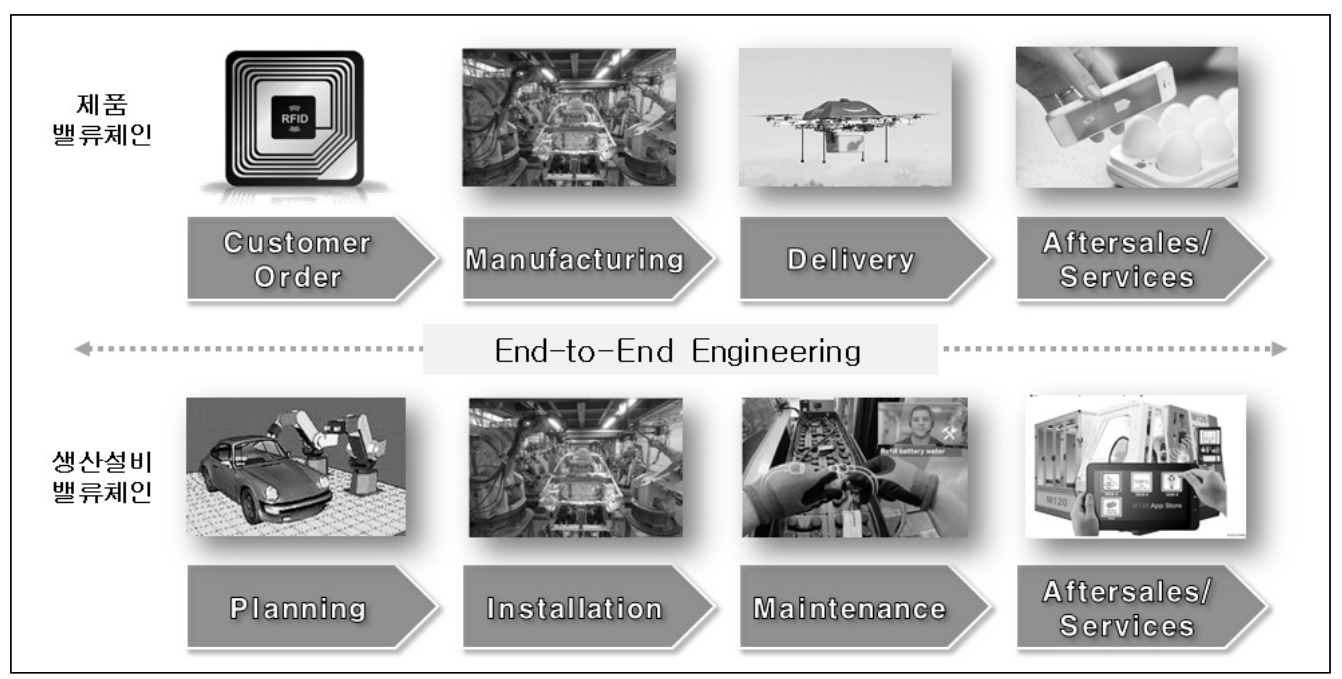

출처: 박형근 (2014) 


\section{2) 소프트웨어에 의한 부가가치 향상}

개인 맞춤 제품의 니즈가 증가하면서 고객 맞춤 솔루션을 제공할 수 있는 소프트웨어의 위상이 강화될 것이다. IoT로 수집된 데이터를 소프트웨어적으로 분석하고 솔루션을 제공함으로써 범용화되고 있는 하드웨어적인 한계를 극복하고 고부가가치의 맞춤 제품으로 거듭날 수 있기 때문이다.

스마트팩토리의 핵심 기능은 개인맞춤 생산을 가능하게 하는 Plug and Produce다. Plug and Produce는 마치 컴퓨터 부품이 연결만 되면 바로 호환되는 것처럼 고객 주문이 변화되어 다른 메이커의 설비가 연결될 때 추가적인 프로그래밍 없이 바로 호환되는 기술을 의미한다. 이러한 환경에서 하드웨어의 경쟁 우위는 약해질 수밖에 없다. 하지만 솔루션을 개발할 수 있는 소프트웨어 경쟁력의 위상은 증가한다. 스마트폰 생태계에서 경험했듯이 스마트팩토리, 스마트 시티, 스마트홈 플랫폼에서 다양한 소프트웨어 또는 앱(App)이 개발될 것이며, 앱스토어가 개설되어 다양한 아이디어가 거래될 것이다. 소프트웨어 경쟁력을 확보한 기업이 4 차 산업혁명 시장을 선점하고 높은 부가가치를 향유할 것이다.

\section{〈그림 5〉 4차 산업혁명과 소프트웨어 혁신}

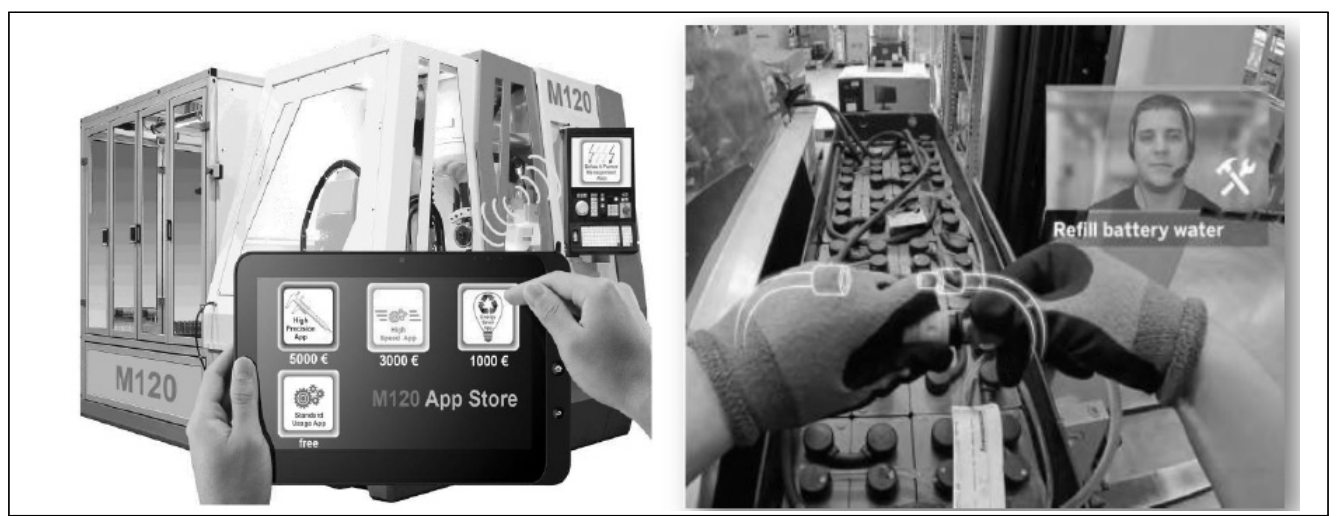

출처: 박형근 (2014)

\section{3) 데이터 분석 기반 제조 서비스의 위상 강화}

4차 산업혁명 시대에 부가가치는 제조보다 서비스 부문에서 더 많이 창출된다. 특히 IoT에 의해 수집된 데이터를 분석하여 누가 얼마나 다양한 서비스를 창출하느냐가 관건이다.

데이터 분석에 기반한 제조 서비스 모델은 이미 많은 기업이 시도하고 있다. 가장 대표적인 
기업은 $\mathrm{GE}$ (General Electric)이며, GE는 항공기 엔진 판매 수익보다 유지·보수를 통한 수익이 더 많다.

$\mathrm{GE}$ 항공은 비행기가 공항에 착륙했을 때 상시 전담팀을 가동하여 엔진 상태를 즉시 점검해

왔다. 엔진에 문제가 있다고 판단되면 새로운 엔진으로 교체하고, $\mathrm{GE}$ 금융과 연계하여 금융리스

상품을 고객사인 항공사에게 판매한다. 항공사 입장에서는 기존 엔진을 보수할 동안 신형 엔진을 즉시 빌려서 사용할 수 있기 때문에 승객들의 불만 없이 비행 서비스를 지속할 수 있다. 하지만 이 모델은 $\mathrm{GE}$ 항공의 속인성 노하우를 $100 \%$ 활용하지 못한다는 단점이 있다. 그리고 결국 고장이 난 후 문제 해결 방식이기 때문에 불황기에 승객 탑승률이 저조할 경우에는 고객 불만이 증가한다. 더욱이 저금리 시대가 장기화되면서 리스금융 수수료의 마진이 낮다는 점도 한계로 작용했다.

$\mathrm{GE}$ 항공은 수천 대의 항공 엔진에 센서를 부착하고, 상태를 실시간으로 진단하는 모델로 서비스를 전환하였다. 중앙관제실에서 센서가 전송한 데이터를 분석하고, 엔진 상태를 원격으로 모니터링하며 유지·보수를 해 주는 서비스였다. IOT 엔진으로 가동 시간과 엔진 상태를 정확히 파악할 수 있기 때문에 GE항공은 고객사의 엔진 상태에 따라 시간당 요율을 차별적으로 책정하는 등 IOT 시대에 맞는 정보 서비스 모델을 급속히 도입하고 있다. 특히 GE항공은 고객사와 엔진 이외에 비행기 모든 데이터에 $\mathrm{GE}$ 가 반드시 접근하는 것을 전제로 계약을 맺는다. 단지 $\mathrm{GE}$ 엔진에 대한 유지·보수 서비스뿐만 아니라 항공사에 에너지 절약 관점의 비행기 운항 컨설팅도 병행할 수 있기 때문이다. 아무리 좋은 설비라도 설비를 작동하는 작업자의 습관이 효율성에 많은 영향을 미친다는 것을 이해하는 것이다. 예를 들면, '착륙할 때 주 날개에 붙어 있는 플랩의 제어 방법을 변경하면 소비되는 연료를 줄일 수 있다' '하강 시 속도를 바꾸면 연비가 개선된다' 등의 컨설팅을 숙련된 항공기 기장에게까지 해줄 수 있는 수준이다(니케이BP, 2015). 이 모든 게 정밀한 데이터 분석에 의해 가능한 모델이다. 


\section{II. 선도국의 전략: 독일과 미국을 중심으로}

\section{1. 독일: 스마트팩토리 기반의 제조 서비스 모델}

독일은 2006년 정보통신기술(Information and Communication Technology, 이하 ICT) 융합산업 정책인 하이테크 2020 사업을 시작하였다. 하지만 제조업과 ICT 융합을 더욱 가속화 하기 위해 2012년부터 인더스트리 4.0이라는 슬로건하에 4차 산업혁명 전략을 강력하게 추진하고 있다.

독일 모델은 스마트팩토리를 중심으로 제조 서비스를 강조하고 있고, 이를 위해 두 가지 전략 (Dual Strategy)을 추진하고 있는 데에 특징이 있다.

첫째, 스마트팩토리 보급을 통해 제조 기반이 해외로 이전되는 것을 막고 본국으로 귀환시키는 데 집중하고 있다. 독일 내수시장의 약 $20 \%$ 로 추정되는 맞춤 제품 선호 고객을 대상으로 스마트 팩토리를 보급하는 것이다. 내수시장에서 테스트베드(test bed)가 성공한다면 향후 유사 팩토리 모델을 해외에 수출하는 중요한 레퍼런스(reference)가 될 수 있다. 아디다스(adidas)가 독일 인스바흐라는 도시에 스피드팩토리(speed factory)를 짓고 개인 맞춤 운동화를 생산하는 시범 사업도 이러한 맥락이다. 아디다스의 스피드팩토리는 이미 미국 등의 주요 도시로 확산되고 있다.

둘째, 스마트팩토리를 구성하는 다양한 하드웨어와 소프트웨어를 해외에 패키지로 판매하려는 목적이다. 스마트팩토리 $\mathrm{EPC}($ Engineering-Procurement-Construction)를 기반으로 다양한 설비, 기자재, 솔루션 외에 교육, 운영, 유지·보수 등 다양한 서비스를 개발하여 패키지로 수출하는 것이다. 이를 통해 중국 등의 부상으로 수익구조가 점차 악화되고 있는 하드웨어 시장을 보완할 수 있는 새로운 제조 서비스 시장을 선점할 수 있다. 
〈그림 6〉 독일 인더스트리 4.0과 Dual Strategy 개요

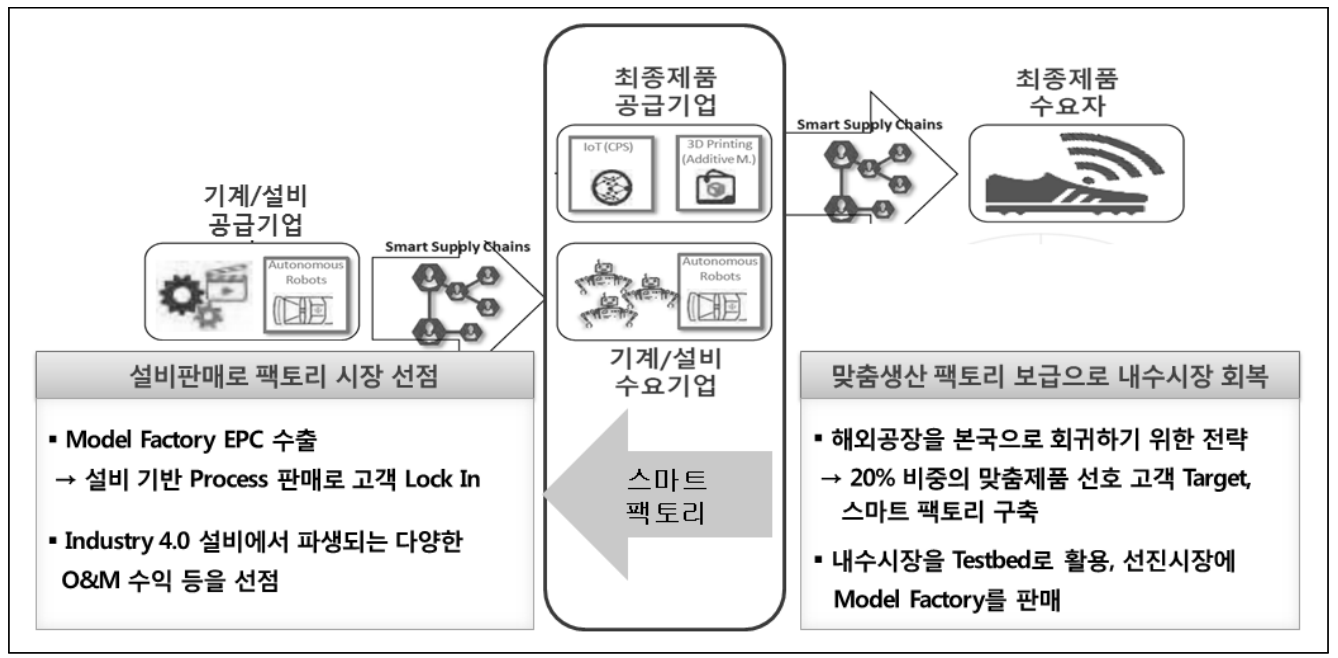

출처: 김은 (2017)

독일은 스마트팩토리 서비스 모델을 위해 디지털 기반의 도제(apprenticeship) 시스템 구축을 강조하고 있다. 숙련공 부족으로 도제 시스템이 4차 산업혁명 시대에 지속하기 어려워졌기 때문이다. 2025년부터는 핵심 생산인구 비중도 30\% 이하로 떨어진다. 숙련공 외에 생산성이 높은 생산 인력마저 부족해지기 때문에 스마트팩토리 보급과 관련된 인재 육성 등이 매우 시급한 과제가 되었다.

이러한 문제를 해결하기 위해 제조 데이터를 수집하고 분석하는 시스템 구축 사업이 확대되고 있다. 이러한 분위기의 중심에는 데이터가 있다. 독일은 제조 데이터 분석에서 주도권을 확보해야 제조 서비스 시장을 선점할 수 있다고 확신하고 있다. 단지 단일 설비를 유지·보수하기 위한 데이터 분석이 아니라 스마트팩토리 전체를 수출하면서 발생되는 데이터를 관리하고 토털 솔루션을 제공함으로써 하드웨어와 소프트웨어 시장 전체를 선점하는 것이 독일의 목표다. 이를 위해 파견 기술자를 단순히 설비를 유지·보수하는 테크니션(technician)이 아니라 스마트팩토리 운영을 총괄하는 데이터 과학자(Data Scientist)로 육성한다는 전략이 추진 중이다.

\section{2. 미국: 스마트시티 기반의 플랫폼 서비스 모델}

미국의 4차 산업혁명은 스마트팩토리가 아닌, 스마트홈 및 스마트폰을 기반으로 시작되었다. 퀄컴을 중심으로 한 ‘올신 얼라이언스(Allseen Alliance)', 구글이 주도하는 ‘스레드 그룹’ 등은 스마트폰과 스마트홈 표준을 선점함으로써 IoT 기반의 4차 산업혁명 시장까지 주도권을 확보 
한다는 구상을 하고 있다. 스마트제조와 관련해서는 $\mathrm{GE}$ 를 중심으로 한 '인더스트리얼 인터넷 (industrial internet) 컨소시엄’이 이 역할을 수행하고 있다.

<그림 7>에서 알 수 있듯이, 독일의 인더스트리 4.0은 제조업 중심에서 원료 조달, 생산 및 가공, 판매 및 유통, 애프터서비스 등 제조업 밸류체인 전체에서 주도권을 확보하기 위한 선택과 집중 전략이다. 반면, 미국의 인더스트리얼 인터넷 컨소시엄은 제조 외에 에너지, 헬스케어, 공공 인프라, 교통 등 다방면의 분야를 모두 포괄하고 있다.

미국의 4차 산업혁명 전략은 스마트홈, 스마트팩토리, 스마트폰, 스마트카 등 다양한 분야에서 자생적으로 조성되고 있는 표준화 컨소시엄을 통합하면서 스마트시티라는 플랫폼 시장을 선점하는 것이다. 미국 정부가 다양한 응용 분야로 확장 가능한 플랫폼 기술에 주력한다면 응용 분야는 미국 기업들이 충분히 기술적 우위로 시장 주도권을 확보할 수 있다는 전략이다.

〈그림 7〉 독일 인더스트리 4.0과 미국 인더스트리얼 인터넷의 전략 비교

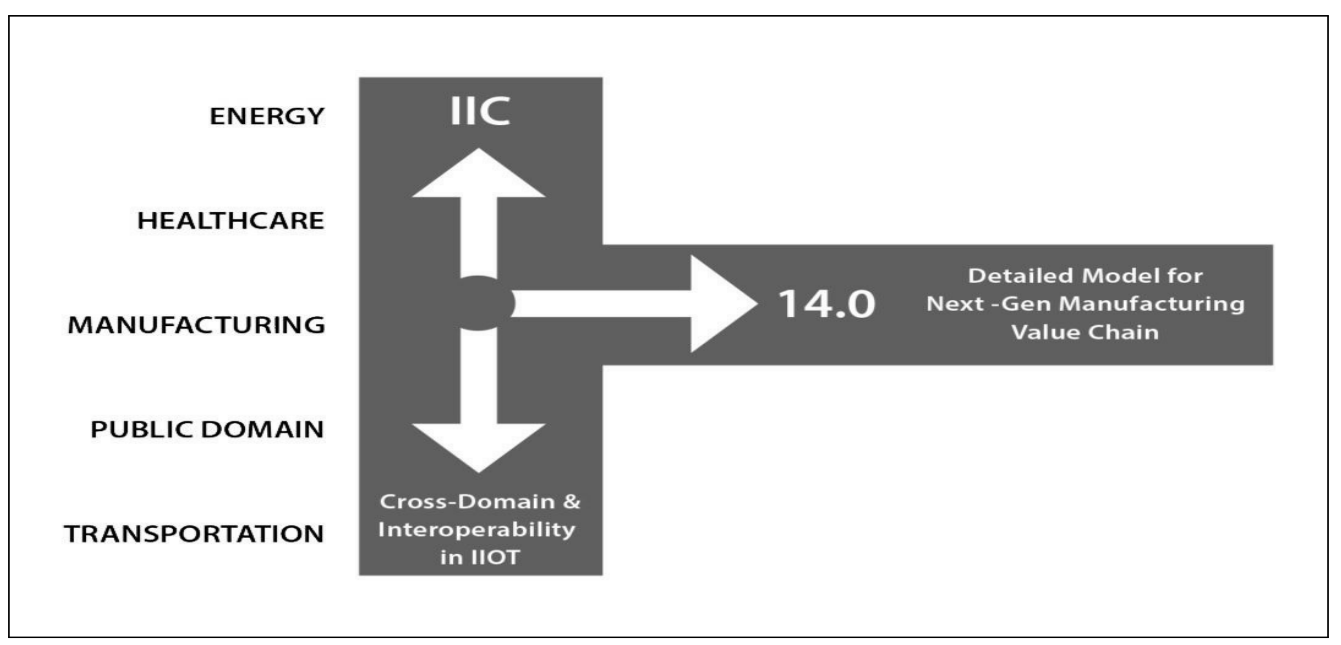

출처: Industrial Internet Consortium 홈페이지 (http://www.iiconsortium.org/) (접속일: 2018.5.27)

미국이 주목하고 있는 4차 산업혁명의 핵심 플랫폼 기술은 사이버물리시스템(cyber physical system)이다. 사이버물리시스템 기술을 확산하는 미국 내 거점은 미국표준기술연구소(National Institute of Standards and Technology, NIST)이며, NIST의 전략은 사이버물리시스템에 기반을 둔 도시 간 스마트시티 제휴를 강화하는 것임을 확인할 수 있다. 다양한 선진국 및 개발도상국 도시와 도시 간 제휴를 확대함으로써 자국 내 스마트시티의 플랫폼을 판매하고, 관련된 제품, 서비스, 인프라 시장에 미국 기업이 자연스럽게 진출한다는 전략이다. 


\section{III. 후발국으로서 우리나라의 대응 전략}

우리나라는 누구도 부인할 수 없는 제조 강국이지만, 4차 산업혁명과 관련해서는 후발국의

위치에 있다. 스마트팩토리 대부분의 설비는 수입에 의존하고 있으며, 4차 산업혁명을 대표하는

센서 및 로봇도 대부분 수입에 의존한다. 스마트폰 제조 경쟁력을 제외하고 스마트홈, 스마트카, 스마트시티 등 4차 산업혁명과 관련된 기술 경쟁력은 독일, 미국 등의 국가와 비교하면 열위에 있다.

이러한 상황에서 우리나라가 4차 산업혁명의 선도국과 대등한 위치에서 협력 또는 경쟁하기

위해서는 하드웨어보다는 소프트웨어에서 승부를 볼 필요가 있다.

자력 엔지니어링, 스마트 센서 및 로봇의 자체 개발 등 하드웨어 중심의 전략은 시간 등 여러 가지 제약 요건을 감안한다면 선도국들과 대등한 위치에서 협력과 경쟁하기는 어렵다. 하지만 하드웨어의 사용자로서 우리는 발생된 모든 데이터의 소유권을 가지게 된다. 데이터 분석의 중요성에 대한 공감대만 확산된다면 방대한 제조 데이터를 기반으로 다양한 제조 서비스를 창출할 수 있으며, 선진국의 하드웨어 제작업체들과도 대등한 입장에서 협력이 용이해진다.

과거에 우리는 제조 데이터의 중요성을 간과했고, 설비 제작 업체들이 우리의 데이터를 자유롭게 사용할 수 있도록 허락했다. 하지만 지금부터는 다양한 이종 설비 및 이종 기기에서 나오는 빅데이터를 수집해야 한다. 이를 기반으로 우리의 숙련 인력에 체화되어 있는 산업 노하우를 결합하고 새로운 제조 서비스 솔루션으로 전환하는 데 모든 역량을 집중해야 한다. 구체적으로 우리가 확보해야 할 솔루션 분야를 제시하면 센서 퓨전(다양한 이종센서에서 발생되는 신호를 수집·종합하여 하나의 신호와 정보로 통합하는 기술) 및 센서 허브(다양한 센서를 플랫폼에서 통합하여 센서 알고리즘 등을 통해 다양한 센서의 기능을 통합적으로 관리하는 기술), 제조 인프라 상태 진단 및 고장 예측 예방 솔루션, 제조 데이터의 보안을 위한 블록체인(거래 정보를 기록한 원장을 특정 기관의 중앙 서버가 아니라 $\mathrm{P} 2 \mathrm{P}$ 네트워크에 분산시켜 참가자가 공동으로 기록하고 관리하는 기술, block chain) 등이 있다.

그리고 4차 산업혁명 시대의 수출 모델은 국가 간 거래가 아니라 도시 간 제휴가 기반이 되어야 한다. 이는 미국의 스마트시티 전략과 같은 맥락인데, 우리가 선도국과 대등한 위치에서 4차 산업혁명 협력 모델을 구상하고자 한다면 우리나라의 스마트시티인 서울과 5대 광역시를 중심으로 할 때 용이할 수 있다. 최근 국가 경쟁력보다 도시 경쟁력이 각광받는 시대가 되고 있으며, 이미 도시 간 제휴는 활발히 체결되고 있다. 특히 서울은 글로벌 Top 10 스마트시티이며, 
헬스케어 등 일부 유망 신산업 측면에서는 Top 3에 속하는 글로벌 스마트시티다. 결국 서울을 중심으로 스마트시티 개발 및 수출 전략을 세우고, 나머지 5대 광역시를 중심으로 특화된 분야(팩 토리, 에너지, 모바일, 헬스케어, 홈)를 선택적으로 육성하는 것이 바람직하다. 스마트시티 경쟁력 이 강화된다면 4차 산업혁명 선도국가의 다양한 도시들로부터 협력 제안이 증가할 것이다. 뿐만 아니라 우리의 도시들과 유사한 발전 모델을 구상하고 있는 다양한 개발도상국과도 사업과 관련해 개발 협업 기회가 증가할 것이다. 


\section{IV. 개발도상국과 협력 방향}

4차 산업혁명 시대에 개발도상국과 협력 방향도 마찬가지다. 우리나라의 특화된 전략 방향,

앞서 제시한 데이터 경제와 연관성이 높은 인프라 사업, 도시 간 제휴 중심의 사업에서 협력을 강화하는 것이 바람직하다.

첫째, 데이터 경제와 관련된 인프라 사업, 예를 들면 IoT 관련 인프라의 $\mathrm{EPC}$ (엔지니어링, 부품조달, 건설)와 O\&M(Operating and Maintenance / 운영 및 유지·보수) 사업을 추진할 수 있다.

하지만 이러한 방안에는 다양한 이슈 사항 및 이해 충돌 문제가 있다. 개발도상국에 데이터 주권을 허락하는 것은 하드웨어를 수출하는 우리 입장에서는 일부 손해가 불가피하다. 우리가 자체 개발한 하드웨어를 수출하면서 발생되는 데이터의 소유권을 요구하고 데이터 분석을 주도한 다면 개발도상국의 제조 서비스 시장을 선점할 수 있기 때문이다.

하지만 자국에서는 수입 설비의 데이터 소유권은 주장하고 수출시장에서는 설비 제작사도 데이터 소유권을 보유해야 한다는 논리는 국제적으로 환영받을 수 있는 전략이 아니다. 결국 데이터는 4 차 산업혁명의 고객 국가인 개발도상국이 소유하는 것이 바람직하다. 대신 우리나라는 데이터 경제를 가능하게 하는 다양한 관련 인프라 사업을 구상하고 개발도상국과 협업하는 전략을 수립해야 한다. 이러한 인프라 사업은 IoT 데이터센터 구축 및 운영 컨설팅, 데이터 기반 시장 맞춤형 솔루션 개발 및 교육사업 등을 예로 들 수 있다.

데이터 경제 및 IoT 사업 모델이 일부 선진국에 국한된다고 생각할 수도 있다. 하지만 최근 개발도상국의 산업발전 모델을 보면 중간 단계를 생략하고 바로 온라인 및 모바일 경제로 전환하는 사례를 많이 볼 수 있다. 아프리카 및 아시아 등에서 모바일 결제시장의 급부상, 드론을 이용한 택배 시스템의 검토, 공유경제를 활용한 다양한 도시 모델 등이 급성장하고 있다. 따라서 데이터 경제 및 IoT 사업은 우리나라가 육성해야 하는 아이템임과 동시에 개발도상국과도 협력 가능한 아이템이 될 수 있다.

둘째, 공여국·수원국 모델이 아니라 공여 도시·수원 도시 모델을 구상하고 도시 간 협력 사업을 발굴해야 한다. 개발도상국의 도시화가 빠르게 진전되면서 다양한 사회문제가 발생할 것이다. 농업 및 공업 부문의 공동화가 빠르게 진행되어 생산성 항상을 위한 근본적인 대책을 요구할 것이다. 도시는 인구과밀로 선진 도시에서만 볼 것이라고 생각했던 다양한 도시문제들이 개발도상국에서도 발생될 것이다. 
우리는 유사한 문제를 모두 경험하였기 때문에 데이터 경제, IoT 사업 모델과 연관시켜 이러한 문제를 새롭게 해결할 수 있다면 다양한 도시와 제휴를 맺고 다양한 사업에서 협력 기회가 생길 수 있다. 동남아 시장의 대표 도시들과 서울이 스마트시티 인프라 제휴를 맺거나 5대 광역시와 유사한 환경을 지닌 다양한 개발도상국 도시를 발굴하여 제휴를 맺는다면 국가 경쟁력 측면에서는 열위에 있었던 4차 산업혁명의 위상이 도시경쟁력 측면에서는 선도국과 대등한 위치에서 사업 협력 및 경쟁이 가능할 것이다. 


\section{〈참고 문헌〉}

김영훈. 2015. 『IoT 기반 스마트팩토리 동향 및 비즈니스 모델 혁신에 관한 연구』.

STEPI 펠로우십 연구 보고서. 세종: 과학기술정책연구원.

2017. 『4차 산업혁명 시대 제조 서비스화 모델과 기술개발 우선순위 도출에

관한 탐색 연구』. STEPI 펠로우십 연구 보고서. 세종: 과학기술정책연구원.

2018. “독일 인더스트리 4.0 전략방향과 시사점”. 2018 4차 산업혁명 스마트

팩토리 심화과정 강의자료. (2018.04.19., KOTRA에서 실시)

김은. 2017. “독일 인더스트리 4.0 기술혁신형 중소/중견기업 현황과 정부의 지원방안"

(비공개 자료). 서울: ICT 융합네트워크.

니케이BP. 2015. 『알기 쉬운 4차 산업혁명』. 서울: 다하미 커뮤니케이션즈. 박형근. 2014. 『인더스트리 4.0, 독일의 미래 제조업 청사진』. 서울: 포스코 경영연구원. 박희석·김은. 2017. “독일의 제조기반 스마트 서비스 추진 현황” 『ICT융합 이슈리포트』.

서울: ICT 융합네트워크.

윤유리. 2017. “제4차 산업혁명과 국제개발협력의 미래” 『개발과 이슈』제29호. 성남: 한국국제협력단.

이정아-김영훈. 2014. 『인더스트리 4.0과 제조업 창조경제 전략』. 대구: 한국정보화진흥원. 정대영. 2018. 『4차 산업혁명과 제조업의 귀환』. 서울: 클라우드 나인.

Acatech. 2015. "Recommendations for the Strategic Initiative Web-based Services for Business”. Berlin: Acatech.

Florian Guldner. 2015. "Market Dynamics Behind Industrie 4.0 and the Industrial Internet of Things”. Massachusetts: ARC Advisory Group.

Michael Dietrich. 2015. “Assistance- and Knowledge-Services for Smart Production: Results from the APPsist Project”. Kaiserslautern: Center for Learning Technology.

Yoram Koren. 2010. “The Global Manufacturing Revolution”, New Jersey: John Wiley \& Sons.

UN 경제사무국 홈페이지: http://esa.un.org/unpd (접속일:2018.05.27.)

Industrial Internet Consortium 홈페이지: http://www.iiconsortium.org/ (접속일: 2018.5.27) 